JANA MIKULOVÁ

Masaryk University, Brno

jmikulova@gmail.com

\title{
DIRECT SPEECH AND DIVERSITY OF VOICES IN SELECTED LETTERS OF CICERO TO ATTICUS I (DIRECT SPEECH)
}

Keywords: direct speech, Cicero, Latin, reported speech, quotation

\begin{abstract}
This paper examines Cicero's use and introduction of direct speech in nine selected letters to Atticus. It shows that despite the informal traits found in the letters, Cicero is not innovative in his choice of means to introduce direct speech. The paper also notes transitional zones on the margin of the domain of direct speech and the interplay of intervening voices. In this way, it contributes to improving the knowledge of direct speech in classical Latin, which is a necessary starting point for research into its development. The analysis is divided into two parts. This part is aimed at the theoretical background, use and introduction of direct speech in the letters to Atticus.
\end{abstract}

\section{Introduction ${ }^{1}$}

This paper examines Cicero's practice of using reported speech in nine selected letters to Atticus. It focuses on direct speech in comparison with other types of reported speech, the means used for the insertion of direct speech into the text, and the interplay between different voices present in these letters. The paper is also aimed at the marginal zone of the domain of direct speech, the examination of which is expected to contribute to a more precise delineation of direct speech. The letters to Atticus are important material for examination because they contain direct speech and at

1 This paper was supported by Czech Science Foundation (project no. GA18-01878S, Introduction of Direct Speech in Latin). 
the same time have informal traits. In addition, Cicero and Atticus are presented as equal partners (Garcea 2002: 131), which need not be the case with Cicero's letters to his friends. In choosing the nine letters examined here (Cic. Att. 2, 12; 5, 21; 6, 2; $7,9 ; 7,11 ; 8,5 ; 9,18 ; 13,38 ; 13,42)$, first letters containing direct speech were identified, and then those letters which are representative as regards modes of inserting diverse "voices" were selected.

\subsection{Diversity of voices in Cicero's letters}

Letters are prone to combinations of elements of written and oral discourse. This is even more true in the case of ancient letters, which - as shown by Garcea (2002) were considered a means of communication between distant persons and were intentionally fashioned to approximate face-to-face conversation. This entails inclusion of such various linguistic traits as allusions to knowledge shared by the author and the addressee, ellipsis, brevity, and corrections and explications of previously written sentences (for more details, see Garcea 2002). In the case of the letters to Atticus, this array of characteristics is supplemented by switches between Latin and Greek, which underscore the conversation-like style between learned friends. In the domain of reported speech, this is reflected in such instances as the omission of introductory elements and any explicit identification of the speaker, which can produce misunderstandings for those who are not familiar with the context. Thus, some passages might seem ambiguous, which can be seen in the use of punctuation marks varying across individual editions according to the editor's interpretation (see, e.g., the discussion concerning letter 9, 18, 3 by Shackleton-Bailey 1960: 45).

Another phenomenon in this respect is the diversity of voices occurring in letters and their insertion into the text. The first level of any conversation, regardless of whether it is oral or written, is the relationship between the speaker and the addressee. Their communication forms the main axis of the letter and creates the background for the insertion of other voices, including their own. In the analyzed letters, this level is characterized by an effort to create and maintain contact with the addressee as well as by politeness strategies, which are similar to those used in face-to-face communication. Examples include questions to the addressee, requests for his reactions, allusions to previous letters or shared experience and knowledge, and the use of such elements as vide 'see', quaeso 'please', and amabo 'please' (see, e.g., Risselada 1989; Garcea 2002; Rosén 2009; Molinelli 2010). The second level consists of reporting other voices. Reporting in the broad sense can be viewed as any indication of the presence of a speaker alien to the current speaker (the letter's author) at the current time (i.e. at the time the letter is written). The means used for this aim are numerous and comprise reported speech of all types, so-called mixed quotations (see below), parentheticals (e.g. ut ait 'as says'), expressions such as "according to", and lexical choice (see Rosén 2013: 257). The focus of this paper lies in one of these strategies, namely direct speech in comparison to other types of reported speech and mixed quotations. Additionally, some strategies which are used to introduce voices alien to the speaker but which lie outside the domain of reported speech as defined below 
will be mentioned. In contrast, lexical choice will not be considered. The paper will be organized as follows: first direct speech will be delineated in contrast to other types of reported speech and mixed quotations, and then selected letters of Cicero will be analyzed and conclusions will be drawn.

\section{Direct speech as a type of reported speech}

Reported speech, or rather reported speech and thought, called "speech and thought representation" by Vandelanotte (2004) and "reported discourse" by Güldemann (2008), has been attracting the attention of linguists for many years. Their main research topics include the definition and subcategorization of reported speech, the syntactical status of direct speech, and the means used to insert reported speech into the discourse. Definitions provided by scholars concerned with the topic include two speakers or deictic centres, that is the current speaker and the reported speaker, ${ }^{2}$ and to a greater or lesser extent also current and reported speech situations. Güldemann (2008: 6; 2012: 18), for example, claimed, "Reported discourse is the representation of spoken or mental text from which the reporter distances him-/herself by indicating that it is produced by a source of consciousness in a pragmatic and deictic setting that is different from that of the immediate discourse". Another discussed issue is the delineation of types of reported speech and their relationships. The main types are considered to be direct and indirect speech, defined by Keizer (2009: 847) as follows: "In DS [direct speech] there are two deictic centers, each speech event having its own speaker, mood, and time and place of utterance, while in IS [indirect speech] there is only one deictic center: the reported speech is presented from the point of view of the speaker of the matrix clause". These two types are associated with formal traits, which are language specific and often comprise changes in deixis, verbal tense, (in)compatibility with certain expressions, and the use of typical syntactic structures.

A different view on direct speech is held by Vries (2008), whose approach is based on the concept of autonymy and considers direct speech to include a wide range of types from (a) "Joop asked, 'Can I have another piece of cake?" (p. 50) through (b) "the question "Who would like coffee?" to (c) "the novel War and Peace" (p. 53) or (d) "the disease of Parkinson" (p. 54). He included all of these types into a category called embedded direct speech. This paper will use the definition based on the existence of two deictic centres and two speech situations, from which it follows that instances such as (c) and (d) will not be considered instances of direct speech and in instances such as (b) context will play important role. In addition, direct speech is conceived of herein as a category of reported speech the primary function of which is reporting. Therefore, for an instance to be classified as direct speech, it will be required to have a reporting function, not merely to express the

2 These terms are used by Spronck (2012: 72 and elsewhere) and Vandelanotte (2009: 3 and elsewhere). 
speaker's stance, strengthen the illocutionary force of the utterance, or provide commentary on an expression.

An even more discussed issue than direct or indirect speech is the intermediate modalities of reported speech, which are characterized by their not clearly defined boundaries. This fuzziness is reflected also in the number of intermediate types distinguished by individual authors as well as the organization of reported speech into a scale (e.g. Vandelanotte 2004) or matrix (Keizer 2009: 846, 861). In addition to the widely recognized and studied "free indirect speech", other types have also been introduced (for more details see, e.g., Vandelanotte 2004, 2009; Keizer 2009). A different approach to the typology was taken by Rosén (2013), who did not create discrete categories, but rather described individual instances as being more or less close to direct or indirect speech. It has been claimed that intermediate types are used mainly in modern literary fiction (Grepl 1988: 51), but less frequently in Latin (see Rosén 2013: 260).

For the present analysis, the most important issue is the delineation of direct speech and indirect speech in contrast to mixed quotations (Davidson 2001: 91-92 and Vries 2008: 58). Vries (2008: 58) defines mixed quotations as structures that "are transparently syntactically (and hence compositional-semantically) part of the matrix clause, and they are citations". Examples include the previous sentence and citations introduced by expressions such as "according to". Vandelanotte $(2009: 6,12)$ considers these to be transitional types of reported speech, but excludes structures such as "according to" or "allegedly" without citation as instances of indirect reported speech. I will follow his approach and these latter examples will be referred to as "voices outside the domain of reported speech". Similarly, switches into Greek, one of the typical characteristics of the letters to Atticus, will not be considered in themselves to be instances of reported speech.

\subsection{Direct speech in Cicero's letters}

In Latin philology and linguistics, direct speech is mentioned mainly in contrast to indirect speech, which has been focused on primarily by grammarians and philologists as a typical feature of classical Latin prose. Direct speech has often been defined negatively in comparison to indirect speech, but increasing interest in particles and other pragmatic devices has supplemented this definition with positive descriptions. For example, Rosén (2013: 255) draws on previous studies on particles or vocatives (Bolkestein 1990: 77-78; Bolkestein 1996: 123; Rosén 2009: 400, 403) and claims that direct speech is "marked not only negatively by absence of the mentioned shifts (i.e. shift of person, mood, pronouns or adverbials ${ }^{3}$ ), but also positively by a large array of extra-propositional items (interjections, vocatives, ...) and interlocutors' expressions (vocatives, modalizers, attenuating and reinforcing, ...)". Latin direct speech can be introduced through various means. The main, although not only, introducer is a verb of speech. The typical verb used in classical Latin is inquam

3 Note by the author. 
'to say', which is usually inserted into direct speech and - according to Spevak (2010: 164) - follows the focus, although this is not a universal rule. Nevertheless, other verbs of speech or thought as well as verbs connected with communication are also used as introducers and appear before, after, or inside direct speech. In addition, a verb of speech can be omitted if it can be inferred from the context, and direct speech can also be introduced by a noun. Occasionally, direct speech can be introduced by two verbs of speech (see Kieckers 1919; TLL s.v. inquam [1772: 72 ff.; 1773: 50 ff.] or s.v. loquor [1668: 69]).

In the letters of Cicero examined herein, 53 instances of direct speech can be found that meet both general criteria for direct speech and Latin-specific ones. They are introduced by the verb inquam 'to say' ${ }^{4}$ in 35 instances, of which 15 are introduced by inquit 'he says', 14 by inquam 'I say', 4 by inquis 'you say', and 2 by inquies 'you will say'. The verb is inserted into direct speech in 30 instances and postposed in 5 instances, in which it follows one-word utterances in 2 instances and short utterances in 3 instances. In other short utterances, however, the verb is in the mid-position. In one instance (Cic. Att. 9, 18, 1), inquam introduces coordinated direct speech, although it is not necessary in this instance from a syntactical point of view (1). In this case, it is equivalent to 'I added'.

(1) "Sic" inquam "agam, senatui non placere in Hispanias iri nec exercitus in Graeciam transportari, multaque" inquam "de Gnaeo deplorabo". (Cic. Att. 9, 18, 1) $)^{5}$

"Well" I said, "I shall take the line that the Senate does not approve of an expedition to Spain or of the transport of armies into Greece, and" I added "I shall have much to say in commiseration of Pompey”. ${ }^{6}$ (transl. by Shackleton-Bailey 1968b: 207)

There are no instances of inquam combined with another preposed verb of speech in a reporting clause. This is related to the fact that the beginning of direct speech in the examined letters coincides with the beginning of the sentence, and so there is no place for the second verb or any other expression, including et 'and', et ille 'and he', sic 'so', and similar ones. However, it is not a rule in all of Cicero's letters; see, for example, tum Quintus 'then Quintus' and at illa audientibus nobis 'but she, as we were hearing' (Cic. Att. 5, 1, 3).

Other verbs are used to introduce direct speech only in two instances, of which one is aio 'to say' and the other respondere 'to answer', both in an ante-position. The verb dicere 'to say' does not introduce direct speech in the examined letters, but it does in others. For example, the form dices 'you will say' introduces hypothetical objections, reactions, and remarks made by the addressee in, for example, the letters Cic. Att. 5, 1, 4; 7, 6, 2. In one instance, direct speech is introduced by the noun

4 The verbs are referred to in the infinitive except for defective verbs lacking the infinitive form, in which case the first person of the present indicative is used.

5 Latin texts are cited according to Library of Latin texts - Series A (2016) and Library of Latin texts - Series B (2016).

6 Translations are quoted according to published translations and need not show preference for the given interpretation of the Latin text. 
epistula 'the letter'. In four instances, direct speech follows the pronoun ille 'he' (tum ille 'then he', at ille 'but he' (2)) or ego 'I' (et ego 'and I', twice). All of these cases appear in a dialogue and signal turn taking.

(2) At ille: "Sed me maxime angit avunculus". (Cic. Att. 13, 42, 1)

He went on: "What distresses me most is my uncle". (transl. by Shackleton-Bailey 1966: 354)

In one instance, direct speech follows the adverb sic 'so, such'. Ten instances are not introduced by any means. Four of these occur in a dialogue (see, e.g., (3)), in which the context and content of the direct speech make it clear that the frameless utterance is a new turn.

(3) "Publius" inquit "tribunatum pl. petit". "Quid ais?" "Et inimicissimus quidem Caesaris, et ut omnia" inquit "ista rescindat". (Cic. Att. 2, 12, 2)

"Publius is standing for the tribuneship", says he. "You don't say so!" "And he is at deadly enmity with Caesar", he replies, "and wants to annul all those laws of his". (transl. by Winstedt 1912: 143)

The remaining six instances are reactions or objections made by Atticus as the addressee or Pompeius, to whom the given letter refers. These are either hypothetical or refer to previously uttered reactions. ${ }^{7}$ In contrast to the instances within dialogues, they are not so easy to identify, particularly when the lack of quotation marks in classical Latin is taken into consideration. In some cases, the identification of the instance as direct speech and of its speaker is based on the context of the letter, while in others knowledge shared between Cicero and Atticus also plays an important role (see (4) below).

(4) "Cottidie ne" inquis "a te accipiendae litterae sunt?" Si habebo cui dem, cottidie. "At iam ipse ades". Tum igitur cum venero desinam. (Cic. Att. 7, 9)

You may wonder whether you have to expect a letter from me every day. The answer is "yes", provided I have people to take them. And if you point out that I shall be with you in person very soon, I answer that when I am I shall stop writing. (transl. by Shackleton-Bailey 1968a: 131)

Except for these latter instances, the opacity of which is due to the private character of the letters, the use of means for introducing direct speech therefore corresponds to classical practice and does not differ even in otherwise rather informal discourse. In comparison to indirect speech, the variability in introducing verbs is low even in long dialogues, where the turns are introduced alternatively by inquit 'he says' and inquam 'I say'. An example is letter 13, 42, in which inquam or inquit introduces 11 of 15 turns and the remaining ones are introduced by et ego 'and I', tum ille 'then he', or zero marking.

It is not clear whether or not the instance in the letter Cic. Att. 7, 11, 3 is hypothetical (see, e.g., Hodgson 2017: 170, note 24). 
Outside the domain of direct speech, inquam has the pragmatic function of strengthening the illocutionary force of the utterance in four instances, in two of which (Cic. Att. 6, 2, 9 and 8, 5, 1) it emphasizes also a repeated expression (TLL s.v. inquam, caput tertium [1782: 5ff.]; Rosén 2009: 411; Pinkster 2015: 355). There are also four instances which would be instances of Vries' (2008: 52f.) “attributive modifying direct speech” or Bonami, Godard's (2008: 359) “pure mention”. One example is (5), where Cicero comments on his mistake in transcribing a Greek word. Another is sentence (6), in which Cicero first quotes a passage from Atticus' letter and then comments on the use of the phrases ut video 'as I see' and et spero 'and I hope'.

(5) "Phliasios" autem dici sciebam et ita fac ut habeas; nos quidem sic habemus. sed

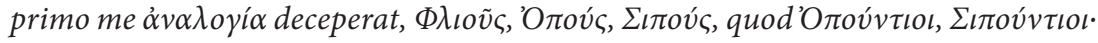
sed hoc continuo correximus. (Cic. Att. 6, 2, 3)

"Phliasians", I know that this is the correct form, and please put it in your copies as I have done in mine. But I was deceived at first by the analogy of Phlius, with Opus and Sipus, which make "Opuntians", "Sipuntians". But I corrected this at once. (transl. by Shackleton-Bailey 1968a: 105)

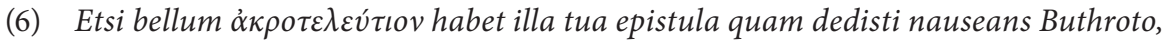
"tibi, ut video et spero, nulla ad decedendum erit mora". Mallem "ut video", nihil opus fuit "et spero". (Cic. Att. 5, 21, 3)

Though your letter written at Buthrotum in sickness had a charming finale, "As I see and hope, there will be nothing to hinder your departure", still I should prefer the phrase "as I see" and there was no need for the words "and hope". (transl. by Winstedt 1912: 401)

From the definition of direct speech adopted herein, however, neither of these instances is considered direct speech as a category of reported speech. Although it could be argued that these instances imply the presence of the reported speaker, the function is not reporting but providing commentary on the use of a word or phrase. ${ }^{8}$ Quotations marks are of no importance here, because the use of quotation marks depends on the editor, who usually tries to employ them in accordance with contemporary rules or practice. In the same vein, the address “To M'. Curius" written on a packet (Tu fasciculum qui est " $M$ '. Curio" inscriptus velim cures... [Cic. Att. 8, 5, 2] 'Would you see that the package addressed "to M'. Curius"...' [transl. by Shackleton-Bailey 1968b: 157]) is also not considered an instance of direct speech.

\subsubsection{Use of direct speech}

Cicero uses direct speech for two main purposes. The first and most frequent one (29 of 53 total instances) is reporting a dialogue presented as having actually occurred in the past. (Needless to say, direct speech cannot be viewed as verbatim transcription of a real utterance.) One of these "real" dialogues even occupies almost the entire letter 13,42 . The second most frequent purpose (14 items) is to express hypothetical

8 Cf. Sznajder (2001: 609f.) with regard to "textual islands". 
reactions by Atticus or hypothetical objections raised by Atticus or another person, which then function as the basis for subsequent argumentation. This use of direct speech corresponds to Rosén's (2013: 261f.) observation that the use of hypothetical voices is one of the usual rhetorical devices used in ancient Roman literature.

In contrast, direct speech is used only marginally (three times) to introduce citations and the cited passage is always taken from a previous letter or alludes to a previous utterance. The scarce use of direct speech to insert citations into the discourse invites for further research into both citation practice by classical authors and its development from classical to late Latin.

\section{Conclusions}

Despite the informal style, direct speech is introduced regularly by the verb inquam, which specialized in introducing direct speech in classical Latin. Even in quite long dialogical passages, it is almost never replaced by synonyms. The form inquam, however, is used also outside the domain of direct speech and has the pragmatic function of strengthening the illocutionary force of the utterance. The most frequent use of direct speech is reporting a dialogue presented as having actually occurred in the past.

In the following part of the examination, entitled Direct speech and diversity of voices in selected letters of Cicero to Atticus II (indirect speech, mixed quotation and comparison with direct speech), use of indirect speech, mixed quotations and the interplay between different voices present in the selected letters will be examined.

\section{References}

Bonami O., Godard D. 2008. On the syntax of direct quotation in French. - 15th International Conference on HPSG. Stanford: 358-377. [available at: halshs-00751080].

Bolkestein A.M. 1990. Sentential complements in functional grammar: Embedded predications, propositions, utterances in Latin. - Vet C., Bolkestein A.M., Nuyts J. (eds.). Layers and levels of representation in language theory: A functional view. Amsterdam, Philadelphia: 71-100.

Bolkestein A.M. 1996. Reported speech in Latin. - Janssen T., Wurff W. van der (eds.). Reported speech. Amsterdam: 121-140.

Davidson D. 2001. Inquiries into truth and interpretation. [ $2^{\text {nd }}$ edition]. Oxford.

Garcea A. 2002. L'interaction épisolaire entre dialogue in absentia et in praesentia chez Cicéron. - Bolkestein A.M. et al. (eds.). Theory and description in Latin linguistics: Selected papers from the XIth International Colloquium on Latin Linguistics, Amsterdam, June 24-29, 2001. Amsterdam: 123-138.

Grepl M. 1988. Reprodukce prvotních výpovědí. - Sborník prací Filozofickéfakulty brněnské univerzity A.36: 51-57.

Güldemann T. 2008. Quotative indexes in African languages: A synchronic and diachronic survey. Berlin, New York. 
Güldemann T. 2012. Thetic speaker-instantiating quotative indexes as a cross-linguistic type.Alphen I. van, Buchstaller I. (eds.). Quotative: Cross-linguistic and cross-disciplinary perspectives. Amsterdam: 117-142.

Hodgson L. 2017. Res Publica and the Roman republic. 'Without body or form'. Oxford.

Keizer E. 2009. The interpersonal level in English: Reported speech. - Linguistics 47.4: 845-866.

Kieckers E. 1919. Zum 'pleonastischen' inquit. - Glotta 10.3: 200-209.

Library of Latin texts - Series A. 2016. Turnhout. [online database, available at: http://apps. brepolis.net/BrepolisPortal/default.aspx].

Library of Latin texts - Series B. 2016. Turnhout. [online database, available at: http://apps. brepolis.net/BrepolisPortal/default.aspx].

Molinelli P. 2010. From verbs to interactional discourse markers: The pragmaticalization of Latin rogo, quaeso. - Calboli G., Cuzzolin P. (eds.). Papers on grammar XI. Roma: 181-192.

Pinkster H. 2015. The Oxford Latin syntax. [vol. 1: The simple clause]. Oxford.

Risselada R. 1989. Latin illocutionary parentheticals. - Lavency M., Longrée D. (eds.). Actes du cinquième Colloque de Linguistique Latine. Louvain-la-Neuve/Borzée, 31 mars - 4 avril 1989. [= Cahiers de l'Institut de Linguistique de Louvain 15]. Louvain-la-Neuve: 367-378.

Rosén H. 2009. Coherence, sentence modification, and sentence-part modification: The contribution of particles. - Baldi P., Cuzzolin P. (eds.). New perspectives on historical Latin syntax. [vol. 1 : Syntax of the sentence]. Berlin, New York: 317-442.

Rosén H. 2013. About non-direct discourse: Another look at its parameters in Latin. - Journal of Latin Linguistics 12.2: 231-263.

Shackleton-Bailey D.R. 1960. Towards a text of Cicero 'Ad Atticum'. Cambridge.

Shackleton-Bailey D.R. (ed. and transl.). 1966. Cicero's letters to Atticus. [vol. 5]. Cambridge. Shackleton-Bailey D.R. (ed. and transl.). 1968a. Cicero's letters to Atticus. [vol. 3]. Cambridge. Shackleton-Bailey D.R. (ed. and transl.). 1968b. Cicero's letters to Atticus. [vol. 4]. Cambridge. Spevak O. 2010. Constituent order in Classical Latin prose. Amsterdam.

Spronck S. 2012. Minds divided: Speaker attitudes in quotatives. - Alphen I. van, Buchstaller I. (eds.). Quotatives: Cross-linguistic and cross-disciplinary perspectives. Amsterdam, Philadelphia: 71-116.

Sznajder L. 2001. Discours indirect et dépendance syntaxique. - Moussy C. (ed.). De lingua Latina novae quaestiones: Actes du Xe Colloque International de Linguistique Latine, Paris-Sèvres, 19-23 avril 1999. Louvain: 609-626.

$\mathrm{TLL}=$ Thesaurus linguae Latinae. 2004. [ $3^{\text {rd }}$ edition, dvd-rom]. Leipzig.

Vandelanotte L. 2004. Deixis and grounding in speech and thought representation. - Journal of Pragmatics 36: 489-520.

Vandelanotte L. 2009. Speech and thought representation in English. Berlin, New York.

Vries M. de 2008. The representation of language within language: A syntactico-pragmatic typology of direct speech. - Studia Linguistica 62.1: 39-77.

Winstedt E.O. (ed. and transl.). 1912. Cicero. Letters to Atticus. In three volumes. [vol. 1]. London, New York. 